\title{
Refractory Burkitt Lymphoma
}

National Cancer Institute

\section{Source}

National Cancer Institute. Refractory Burkitt Lymphoma. NCI Thesaurus. Code C8847.

Burkitt lymphoma that is resistant to treatment. 